\title{
腎グルコーストランスポーターと抗糖尿病薬
}

\author{
荒川健司

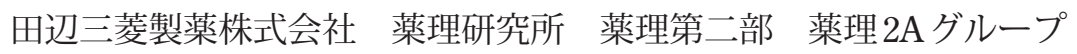 \\ 于 335-8505 埼玉県戸田市川岸2-2-50
}

\section{Renal Glucose Transporter and Anti-diabetic Agent}

\author{
Kenji Arakawa \\ Metabolic Disorders, Pharmacology Laboratory, Mitsubishi Tanabe Pharma Corporation \\ 2-2-50, Kawagishi, Toda-shi, Saitama 335-0015, Japan
}

Plasma glucose is continuously filtered through the glomerulus in the kidney and then reabsorbed via the transcellular transport systems. Glucose reabsorption in the kidney is mediated by a distinct class of transporters such as sodium-glucose cotransporters (SGLTs). Most of filtered glucose is reabsorbed by the low affinity/high capacity SGLT2 located in the proximal renal tubule. SGLT2 inhibitors, such as T-1095, enhance urinary glucose excretion, and consequently lower blood glucose level and control energy balance in a negative direction. The principle behind SGLT inhibition involves the amelioration of diabetic conditions without increasing body weight or the risk of hypoglycemia. A number of SGLT2 inhibitors are being developed and studies have suggested the therapeutic potential and safety of these drugs for the treatment of diabetes.

Key words : diabetes / SGLT / urinary glucose excretion / anti-diabetic agent

\section{1.はじめに}

糖尿病は, 英語（ラテン語）で Diabetes mellitus と 表される. その語源は, “diabetes：サイフォン”と “mellitus：蜂蜜のような甘い味”であり，甘い尿が 間断なく出てくるという糖尿病の症状に由来してい る. 尿中グルコースの出現は, 糖尿病発見のきっか けとなることが多く, 病気の名称に “糖尿” と付い ていることから，尿糖自体が諸症状の元になるかの ような印象を受けがちである。しかしながら，糖尿 病の問題の本質は, 慢性の高血糖に起因する様々な 合併症である.さらに, 腎臓の生理学では, 「糖尿病 患者の尿へのグルコースの放出は, 高血糖の悪影響 から体内諸臟器を保護するためのひとつの防御機構 である」とされている ${ }^{11}$. そうであれば，このような

Tel : 048-433-8050 Fax : 048-433-8161

E-mail : arakawa.kenji@mu.mt-pharma.co.jp
生体の防御機構をうまく利用して, 糖尿病の治療が 出来るのではないか。このような考えを基に, 腎臓 での糖再吸収を抑制するナトリウムーグルコース共 輸送体（Sodium-glucose cotransporter : SGLT) 阻害 薬の研究がスタートした ${ }^{2}$.

本稿では, SGLT阻害薬のコンセプトと阻害薬の一 つであるT-1095を用いて得られた動物実験の成績を 紹介し, 新しい糖尿病治療薬としての可能性を述 べる.

\section{2. 糖尿病とエネルギー摂取バランス}

長い飢餓との戦いの中で, ヒトは生命維持のため に必要なグルコースを供給するために, グルカゴン, アドレナリン, 糖質コルチコイド, 成長ホルモンな ど，血糖值を上昇させる多くの仕組みを身に付けて きた. 一方, 高濃度のグルコースは蛋白の変性作用 を持つので, 血糖值はある一定の範囲にコントロー 
ルする必要があるが，血糖值を下げるホルモンはイ ンスリン唯一つである。颃そらく, 飢餓の時代にお いては，インスリンがあれば十分であったのであろ う。ところが今日, 人々は飢餓から解放され, 飽食 の時代となった. さらに, 高脂肪食摂取量の増加と, 労働の機械化や車社会によるエネルギー消費の減少 が加わり, 相対的にエネルギー過剩の状態が形成さ れ，血糖值を下げるためのインスリンの必要量が増 加した，不幸にして必要量が膵臓のインスリン分泌 の能力を超えてしまった人々は，インスリン以外に 血糖值を下げる仕組みがないために，血糖值を正常 に保つことが出来なくなった．そして，いったん高 血糖が生じると,「糖毒性 (glucose toxicity)」によっ てインスリン分泌能とインスリン感受性の両者が障 害され，更に血糖值が上昇した ${ }^{3)}$ ．この悪循環を辿っ た結果, 多くの人で糖尿病が発症・進展したのであ る.これが, 現在の糖尿病患者激増の背景だと考え られている.

糖尿病の治療においては, 摂取エネルギー（カロ リー）を制限する食事療法と，エネルギーを消費す る運動療法によって, エネルギーバランスを是正す ることが基本とされている。しかし, 厳格な食事療 法, 運動療法を長期に渡って継続することは非常に 困難であり, 多くの場合薬物治療が導入されること となる. 高血糖を速やかに是正できるものとしては, インスリン製剤がある。インスリンは，過剩な血中 グルコースを骨格筋, 肝臓そして脂肪組織に取り込 ませることで, 血糖值を低下させる. したがって, エネルギー過多の状態でインスリン治療を続けると, 過剩に摂取したカロリーが体内に蓄積されることに なり, 肥満を誘導し, 長期的には血糖コントロール を再悪化させてしまうことが多い4)．スルホニルウレ ア剂を始めとするインスリン分泌促進薬や，インス リン抵抗性を改善するグリタゾン系薬剤についても, 同様である ${ }^{4}$ ．高血糖を速やかに正常化する（対症療 法）とともに，エネルギーバランスを負に制御でき る（原因療法）薬剂が理想であるが，その両面を兼 ね備えた薬剤は，これまでにはなかった，SGLT阻害 薬は，過剰な血中グルコースを直接尿中に排出する ことで血糖值を正常化し, 同時にエネルギーバラン スをも是正できる，理想的な糖尿病治療薬となりう る可能性がある.

\section{3. 腎でのグルコース再吸収とその阻害}

血中のグルコースは, 腎糸球体で濾過を受けて原 尿中に送られた後, 腎尿細管で再吸収される。グル コース濃度の高い近位尿細管起始部には低親和性で
輸送能の大きい $\mathrm{SGLT}^{5,6)}$ が, 濃度の低くなる遠位部 には高親和性で輸送能の小さいSGLT17,8) が発現して おり，二段構えでグルコースの再吸収を行っている. この機構により, 正常血糖時にはグルコースはほぼ $100 \%$ 再吸収され, 循環血中に戻ってくる. 生体が限 られた食物で生存してゆくために, 一度取り込んだ エネルギーを無駄なく活用する, 見事なシステムが 構築されているのである.

しかし，エネルギーの過剩が問題になっている時 代においては，必ずしもこのシステムが完璧に機能 する必要はないのかもしれない. 実際, 血糖值は正 常なのにグルコースの再吸収能が低いために尿糖陽 性となる，いわゆる腎性糖尿の人が，全人口の $0.5 〜$ 1.0\%存在している ${ }^{9}$. 原因は腎特異的に発現している SGLT2の遺伝子異常であることが明らかにされつつ ある ${ }^{10)}$ 。しかしながら, これらの人に腎や他の㵴器 の機能異常は認められず, 全くの健康体である ${ }^{11)}$. 尿路感染の頻度も, 健常人との間に差を認めない ${ }^{11}$. ちなみに, 糖尿病患者で尿路感染のリスクが高いの は事実 ${ }^{12)}$ であるが，健常人の尿中の痕跡程度のグル コース濃度が, 細菌の増殖に至適なグルコース濃度 を既に超えていることが報告されており ${ }^{13)}$, その要 因が尿糖の増加であるというのは大きな䛊解である. 現在のところ, 高血糖による脱水や神経障害, 血管 障害等に起因する感染防御能の低下が, 糖尿病患者 の尿路感染の主な理由であると考えられている ${ }^{14)}$.

腎臓のグルコースの再吸収には予備能力があり, 正常血糖時（血糖值が $100 \mathrm{mg} / \mathrm{dL}$ 付近）には，およ そ30\%のSGLTの働きでほぼ完全にグルコースは再吸 収される。一方, 血糖值が $200 \mathrm{mg} / \mathrm{dL}$ 近くになると, 原尿中の糖の再吸収にほとんど全てのSGLTが動員さ れるようになる。 そして, 糖尿病患者のように食後 の血糖值が $200 \mathrm{mg} / \mathrm{dL}$ 超える場合に, 再吸収しき れない糖が尿糖として排出されてくるのである ${ }^{1)}$.

SGLT阻害薬は，グルコースの再吸収過程を阻害す るので, 尿中にグルコースが出てくる血糖值の閾值 を低下させる。 しかし, 正常血糖時には, 腎蔵によ るグルコースの再吸収に十分な予備能力があるので, 例えば薬物で $50 \%$ の SLTTを阻害しても，尿中にグル コースは排出されない. 一方, 糖尿病患者のように 血糖值が高く, 全てのSGLTが動員されている場合に は, SGLTを阻害すれば阻害しただけ尿糖排泄が増加 する (Fig. 1) 15, 16)。実際, 高血糖を呈するモデル動 物にSGLT阻害薬を投与すると, 尿糖排泄は著しく増 加し, 血糖值は正常值近くまで速やかに低下したが, 血糖值が正常の動物に同じ用量のSGLT阻害薬を投与 しても，尿糖排泄量の増加および血糖值の低下は, 共に僅かしか観察されなかった ${ }^{17 〜 20)}$ 。つまり, 

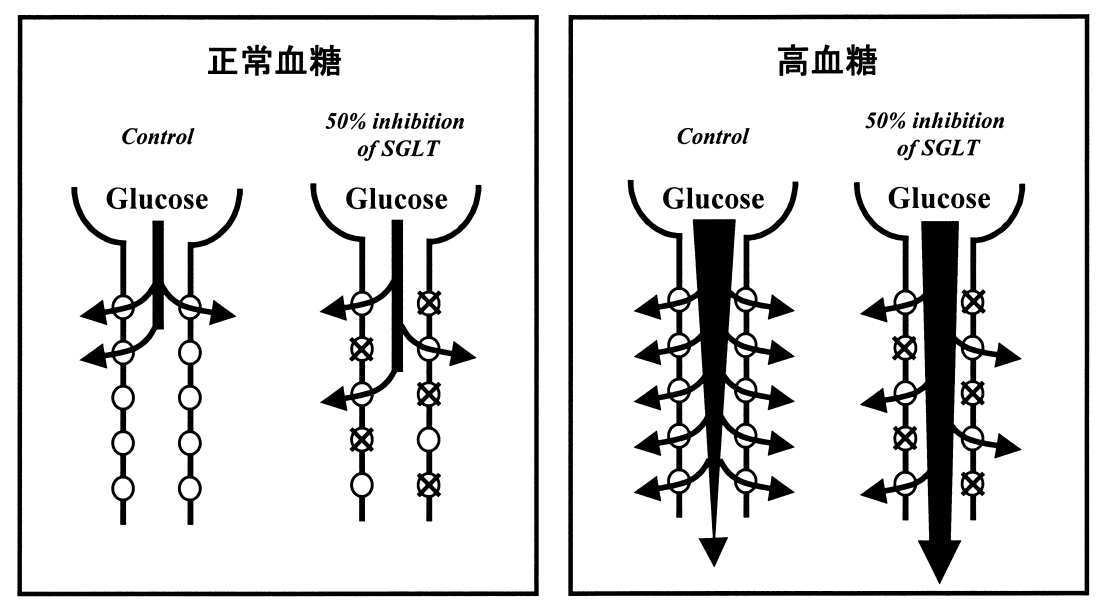

Fig. 1 Schematic representation of the effect of SGLT inhibitor on glucose reabsorption in renal tubules. Since SGLTs are abundantly expressed in renal proximal tubules, only a part of the SGLT function is sufficient for complete reabsorption of filtered glucose at normal glucose levels. On the other hand, the reabsorption system is saturated under hyperglycemic conditions. Therefore, inhibition of SGLT would excrete larger amount of glucose into urine in hyperglycemic than normoglycemic states.

SGLT阻害薬は, 血糖值の高い状態でより顕著な効果 を発揮し，正常血糖値には作用し難く，低血糖誘発 の危険が少ない，という特徵を有していると考えら れる.

\section{SGLT阻害薬の抗糖尿病作用}

T-1095は, SGLT阻害物質として知られる天然物の phlorizinの誘導体である（Fig. 2) が, phlorizin とは 異なり，高い経口吸収性を有している。 T-1095は工 ステル型プロドラッグであり，小腸から吸収された 後, 主として肝臓のエステラーゼで加水分解され, 活性体のT-1095Aに変換される (Fig. 3) ${ }^{16}$. T-1095 お よびT-1095AのヒトSGLT1およびSGLT2 に対する in vitro での阻害作用（50\% 阻害濃度： $\mathrm{IC}_{50}, \mu \mathrm{M}$ ）は, それぞれ $22.8,2.3$ および $0.20,0.05$ である ${ }^{15)}$.

一方，各種の細胞にグルコースを取り込む働きを するグルコーストランスポーターGLUT1に対する阻 害作用は極めて弱く, T-1095 は SGLT2 選択的な阻害 剂である ${ }^{15)}$.

\section{1 高血糖是正作用}

ラットにストレプトゾトシン（STZ）を静脈内投与 すると, 膵 $\beta$ 細胞が破壊されてインスリン分泌不全 を来たし, 高血糖が惹起される.この1型糖尿病モデ ル動物にT-1095を投与すると, 尿糖排泄が増加し, 血糖値が速やかに正常值近くまで低下した ${ }^{19)}$. 同様 の高血糖是正作用が, $\mathrm{KK}-\mathrm{A}^{\mathrm{y}}$ マウス, $\mathrm{db} / \mathrm{db}$ マウス, GKラット, ZDFラット等の肥満型および非肥満型の
A)<smiles>O=C(CCc1ccc(O)cc1)c1c(O)cc(O)cc1OCC(O)C(O)C(O)CO</smiles>

B)<smiles>Cc1cc(O)c(C(=O)CCc2ccc3occc3c2)c(OC2OC3OC(C2O)C(O)C(O)C3O)c1</smiles>

C)<smiles>Cc1cc(O)c(C(=O)CCc2ccc3occc3c2)c(OCC(O)C(O)C(O)C(O)C(O)CO)c1</smiles>

Fig. 2 Chemical structure of phlorizin (A), T-1095 (B), and T-1095A (C).

2 型糖尿病モデル動物においても観察された ${ }^{15 \sim 18, ~ 20) . ~}$ また, これらの糖尿病モデル動物にT-1095を 4 8 週 間程度連続して投与すると, 随時および空腹時の血 糖值の低下に加えて, 長期間の血糖コントロールの 


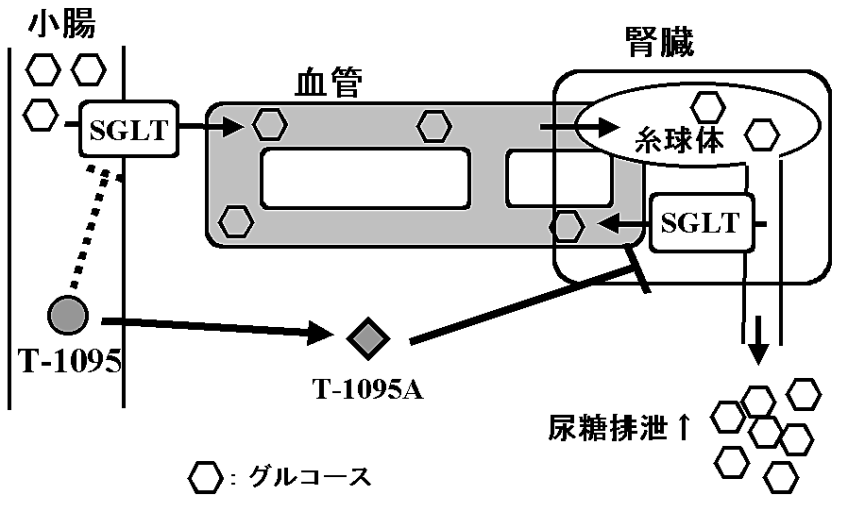

Fig. 3 The mechanism of action of T-1095. T-1095 is metabolized to T-1095A in the liver and the metabolite is thus detected in the blood after oral T-1095 administration. Therefore, when T-1095 is taken orally, intestinal SGLT and renal SGLT are inhibited by T-1095 and T-1095A, respectively. Since the inhibitory effect of T-1095A on SGLT is much more potent than that of T-1095, oral T-1095 exerts a hypoglycemic effect mainly by inhibiting renal SGLT and by increasing urinary excretion of glucose.

指標である $\mathrm{HbA}_{1 \mathrm{C}}$ 值の低下を認めた $\left.{ }^{15} \sim 18,20 \sim 25\right)$. こ のように, T-1095は, あらゆるタイプの糖尿病モデ ル動物で高血糖是正作用を発揮した。

\section{2 糖毒性の解除}

\subsection{1 インスリン分泌改善作用}

ZDFラットは幼若期にはインスリンの過剩分泌を 認めるが，次第にインスリン分泌が低下し，著明な 高血糖を呈するようになるモデル動物である．高血 糖を示すようになったZDFラットを一晚絶食し, 経 ログルコース負荷試験（OGTT）を行うと，顕著な血 糖上昇（耐糖能異常）とインスリンの初期分泌の消 失が観察される。ところが， T-1095を長期間にわた って投与し，高血糖を是正しておくと，インスリン の初期分泌が維持され，またグルコース負荷による 血糖上昇も抑制された ${ }^{26)}$ 。このような $\mathrm{T}-1095$ の膵へ の効果は, 新生児期にSTZを投与して膵 $\beta$ 細胞を障 害した nSTZラットや遺伝的にグルコース依存性のイ ンスリン分泌に障害を持つ GKラットにおいても同様 に認められた 17, 23, 24). また, db/db マウスにT-1095 を長期投与して血糖值をコントロールすると，膵臓 のインスリン含量の低下を一部阻止することができ た ${ }^{22)}$. SGLT阻害薬は，インスリン分泌に頼ることな く高血糖を是正することから, 膵 $\beta$ 細胞に負担をか けずに，高血糖によるインスリン分泌不全の惹起と いう悪循環を絶つことが出来るものと考えられる.

\subsection{2 インスリン抵抗性改善作用}

nSTZラットにグルコースクランプを施行すると， 肝臓および末梢組織でのインスリン感受性の減弱 （インスリン抵抗性の増大）が認められる。また, STZラットやnSTZラットの骨格筋を摘出して調べて みると，インスリン依存性のグルコースの取り込み が著しく低下していることが確認される，ところが， T-1095を 4〜8週間投与して，これらの動物の血糖值 を正常值近くでコントロールすると, 肝臓および末 梢（骨格筋）のインスリン感受性をほぼ正常レベル に維持することが出来た ${ }^{17,21)}$.

一方，ZDFラットのインスリン感受性をグルコー スクランプ法で検査してみると, 幼若期の未だ高血 糖が顕在化していない時期から末梢のインスリン抵 抗性の増大が見られる. T-1095の投与でZDFラット の血糖值を長期間コントロールすると, 未梢のイン スリン抵抗性は完全には回復しないが, 肝のインス リン感受性は, ほとんど正常血糖動物に近いレベル にまで改善させることが出来た ${ }^{18)}$ 。このことは, ZDFラットのように末梢のインスリン抵抗性に端を 発する糖尿病においても, 高血糖が特定の臟器（こ のモデルでは肝蔵）のインスリン感受性を悪化させ， 更に血糖コントロールを増悪させていくことを強く 示唆するものである. また, 肝インスリン抵抗性の メカニズムの一つとして, glucokinaseの核から細胞 質へのトランスロケーションの障害が注目されてい る 27) が，T-1095の投与によってこの障害が回復する ことも明らかとなった ${ }^{28)}$.

糖毒性によってインスリン抵抗性が増大した組織 では，インスリンシグナル伝達機構のうち, Akt/プ ロテインキナーゼ B (PKB) の活性が極端に低下し ていた，一方で，その上流シグナルであるインスリ ン受容体から phosphatidylinositol 3-kinase（PI3キナ 一ゼ）活性化の経路は, むしろ代償的に活性が増加 していた. T-1095の投与で高血糖を是正し，インス リン抵抗性を改善すると, この両方の変化が正常化 に向かうことが見出された $\left.{ }^{29}, 30\right)$. このことから, 高 血糖が持続すると, PI3 キナーゼと Akt/PKBの間の 伝達過程に障害が生じ, インスリン抵抗性を惹起し ている可能性が考えられる.

\subsection{3 糖尿病性合併症の発症・進展抑制作用}

糖尿病性腎症の発症は, 尿中マイクロアルブミン の上昇によって検知される. STZラットや $\mathrm{db} / \mathrm{db}$ マ ウス, KK-A $\mathrm{A}^{\mathrm{y}}$ ワウスどの糖尿病モデル動物でも, 高血糖の持続に伴って尿中アルブミンの増加が認め られる. T-1095の長期投与は, これらの動物の尿中 アルブミンを有意に低下させた ${ }^{15,20,22)}$. また, $\mathrm{db} / \mathrm{db}$ マウスでは, 糖尿病性腎症に特徵的なメサンギウム 領域の拡大を認めるが, T-1095 はこの変化を軽減さ 
せた ${ }^{22)}$. STZラットでは, 腎の重量増加, 尿細管上 皮の空胞化，およびGLUT2 の発現レベルの増加など を認めるが, T-1095 はこれらの変化も阻止した ${ }^{20)}$. 以上のことから, SGLT阻害薬には糖尿病性腎症の予 防効果，あるいは治療効果が期待できるものと考え られた。

GKラットにTail-flick 試験を行うと，長期間高血糖 に曝されていた高週齢の個体において, 熱刺激に対 する反応性の低下が観察された，ところが，T-1095 で血糖值をコントロールしておくと，その変化は明 らかに抑制された 25). 従って, SGLT阻害薬によって, 糖尿病性神経障害の発症・進展が抑止できる可能性 もある。

\section{5. おわりに}

「余分な血糖を尿糖として体外に排出する」とい う単純な機序で, 高血糖を長期間継続的に是正しう ることが明らかとなった。 また, SGLT阻害薬には, 糖毒性解除を介した治療効果として，インスリン分 泌不全の改善，インスリン抵抗性の改善，更には合 併症の発症・進展の抑制等の効果も期待できること が示された．また，SGLT阻害薬には，現行の糖尿病 治療薬が抱える体重増加, 低血糖, 消化器症状等の 副作用の問題がないばかりか，体重に関しては，エ ネルギーバランスを負に制御することによる積極的 な減量効果にも期待が持たれている.

最近, BMS 社の SGLT2 阻害薬 dapagliflozin の 2 型 糖尿病患者 47 名を対象とした初期第 2 相臨床試験の 結果が公表され，2週間の投与で食後血糖值と空腹時 血糖值の低下が認められたことが報告された ${ }^{31}$ 。 現 在，他の多くの製薬メーカーも SGLT阻害薬の開発を 進めており $32 \sim 34)$, 我々も T-1095の後継品の開発に力 を注いでいる. 今後, SGLT阻害薬の臨床現場での有 用性が，更に明らかになっていくことを期待して いる.

\section{文 献}

1) Deetjen P, Baeyer HV, Drexel H :"Textbook of Nephrology", Massry SG, Glassock RJ eds., pp.90-94, Williams \& Wilkins, Baltimore, MD (1995)

2) Tsujihara $K$, Hongu M, Saito K, Inamasu M, Arakawa K, Oku A, Matsumoto M : Chem. Pharm. Bull., 44, 11741180 (1996)

3) Rossetti L: Clin. Invest. Med., 18, 255-260 (1995)

4) Nathan DM, Buse JB, Davidson MB, Heine RJ, Holman RR, Sherwin R, Zinman B : Diabetologia, 49, 1711-1721 (2006)

5) Mackenzie B, Loo DD, Panayotova-Heiermann M,
Wright EM : J. Biol. Chem., 271, 32678-32683 (1996)

6) Kanai Y, Lee WS, You G, Brown D, Hediger MA : J. Clin. Invest., 93, 397-404 (1994)

7) Wright EM, Hirayama B, Hazama A, Loo DD, Supplisson S, Turk E, Hager KM : Soc. Gen. Physiol. Ser., 48, 229-241 (1993)

8) Wright EM, Turk E, Hager K, Lescale-Matys L, Hirayama B, Supplisson S, Loo DD : Acta. Physiol. Scand. Suppl., 607, 201-207 (1992)

9) 四家敏秀: 「図解腎臟内科学テキスト」, 富野康日己編, p250-251, 中外医学社 (2004)

10) Santer R, Kinner M, Lassen CL, Schneppenheim R, Eggert P, Bald M, Brodehl J, Daschner M, Ehrich JH, Kemper M, Li Volti S, Neuhaus T, Skovby F, Swift PG, Schaub J, Klaerke D : J. Am. Soc. Nephrol., 14, 2873-2882 (2003)

11) Brodehl J, Oemar BS, Hoyer PF : Pediatr. Nephrol., 1, 502-508 (1987)

12) $\mathrm{Hu} \mathrm{KK}$, Boyko EJ, Scholes D, Normand $\mathrm{E}$, Chen $\mathrm{CL}$, Grafton J, Fihn SD : Arch. Intern. Med., 164, 989-993 (2004)

13) Shehata TE, Marr AG : J. Bacteriol., 107, 210-216 (1971)

14) Patterson JE, Andriole VT : Infect. Dis. Clin. North Am., 9, 25-51 (1995)

15) Oku A, Ueta $K$, Arakawa $K$, Ishihara $T$, Nawano $M$, Kuronuma Y, Matsumoto M, Saito A, Tsujihara K, Anai M, Asano T, Kanai Y, Endou H : Diabetes, 48, 1794-1800 (1999)

16) Tsujihara K, Hongu M, Saito K, Kawanishi H, Kuriyama K, Matsumoto M, Oku A, Ueta K, Tsuda M, Saito A : J. Med. Chem., 42 5311-5324 (1999)

17) Oku A, Ueta K, Nawano M, Arakawa K, Kano-Ishihara T, Matsumoto M, Saito A, Tsujihara K, Anai M, Asano T: Eur. J. Pharmacol., 391, 183-192 (2000)

18) Nawano M, Oku A, Ueta $K$, Umebayashi I, Ishirahara $T$, Arakawa K, Saito A, Anai M, Kikuchi M, Asano T : Am. J. Physiol., 278, E535-E543 (2000)

19) Oku A, Ueta $K$, Arakawa K, Kano-Ishihara $T$, Matsumoto M, Adachi T, Yasuda K, Tsuda K, Saito A : Biol. Pharm. Bull., 23, 1434-1437 (2000)

20) Adachi T, Yasuda K, Okamoto Y, Shihara N, Oku A, Ueta K, Kitamura K, Saito A, Iwakura T, Yamada Y, Yano H, Seino Y, Tsuda K : Metabolism, 49, 990-995 (2000)

21) Oku A, Ueta K, Arakawa K, Kano-Ishihara T, Matsumoto T, Adachi T, Yasuda K, Tsuda K, Ikezawa K, Saito A : Jpn. J. Pharmacol., 84, 351-354 (2000)

22) Arakawa K, Ishihara T, Oku A, Nawano M, Ueta K, Kitamura K, Matsumoto M, Saito A : Br. J. Pharmacol., 132, 578-586 (2001)

23) Yasuda K, Okamoto Y, Nunoi K, Adachi T, Shihara N, Tamon A, Suzuki N, Mukai E, Fujimoto S, Oku A, Tsuda K, Seino Y : Horm. Metab. Res., 34, 217-221 (2002)

24) Nunoi K, Yasuda K, Adachi T, Okamoto Y, Shihara N, 
Ueno M, Tamon A, Suzuki N, Oku A, Tsuda K : Clin. Exp. Pharmacol. Physiol., 29, 386-390 (2002)

25) Ueta $K$, Ishihara $T$, Matsumoto $Y$, Oku A, Nawano $M$, Fujita T, Saito A, Arakawa K : Life Sci., 76, 2655-2668 (2005)

26) 浅野知一郎: 内分泌 - 糖尿病科, 8, 168-173 (1999)

27) Fujimoto Y, Donahue EP, Shiota M : Am. J. Physiol., 287, E414-E423 (2004)

28) Fujimoto Y, Torres TP, Donahue EP, Shiota M : Diabetes, 55, 2479-2490 (2006)

29) Nawano M, Ueta K, Oku A, Arakawa K, Saito A, Funaki M, Anai M, Kikuchi M, Oka Y, Asano T : Biochem. Biophys. Res. Commun., 266, 252-256 (1999)

30) Oku A, Nawano M, Ueta K, Fujita T, Umebayashi I, Arakawa K, Kano-Ishihara T, Saito A, Anai M, Funaki M, Kikuchi M, Oka Y, Asano T : Am. J. Physiol., 280, E816E824 (2001)

31) Komoroski B, Brenner E, Li L, Vachharajani N, Kornhauser D : Diabetes, 56 (Suppl. 1), A49 (2007)

32) Katsuno K, Fujimori $Y$, Takemura $Y$, Hiratochi M, Itoh F, Komatsu Y, Fujikura H, Isaji M : J. Pharmacol. Exp. Ther., 320, 323-330 (2007)

33) Isaji M : Curr. Opin. Investig. Drugs, 8, 285-292 (2007)

34) Meng W, Ellsworth BA, Nirschl AA, McCann PJ, Patel M, Girotra RN, Wu G, Sher PM, Morrison EP, Biller SA, Zahler R, Deshpande PP, Pullockaran A, Hagan DL, Morgan N, Taylor JR, Obermeier MT, Humphreys WG, Khanna A, Discenza L, Robertson JG, Wang A, Han S, Wetterau JR, Janovitz EB, Flint OP, Whaley JM, Washburn WN : J. Med. Chem., 51, 1145-1149 (2008)

(Received 11 March 2008;

Accepted 17 March 2008)

\begin{tabular}{|c|c|}
\hline 著者略歴 & \\
\hline 荒川 健司 & (あらかわ けんじ) \\
\hline 1983 年 3 月 & 筑波大学第二学群農林 \\
\hline & 学類生物応用化学主専 \\
\hline & 攻卒業 \\
\hline 1985年 3月 & 筑波大学大学院修士課 \\
\hline & 程環境科学研究科修了 \\
\hline 1985 年 4 月 & 田辺製薬株式会社入社 \\
\hline 2004 年 2 月 & 農学博士 \\
\hline 現 在 & 田辺三菱製薬株式会社 \\
\hline & 薬理研究所薬理第二部 \\
\hline & 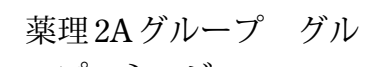 \\
\hline & ープマネージャー \\
\hline
\end{tabular}

